\title{
Peningkatan Hasil Belajar Melalui Penerapan Model Jigsaw pada Siswa Sekolah Dasar
}

\author{
Afif Khoiruddin, Imaniar Purbasari, dan Deka Setiawan
}

Universitas Muria Kudus, Indonesia.

Email:afifkhoiruddin76@gmail.com

\section{Info Artikel}

Sejarah Artikel:

Diserahkan 22 Agustus 2021

Direvisi 29 November 2021

Disetujui 30 November 2021

Keywords:

Jigsaw, Learning Outcomes,

Elementary Students

\section{Abstract}

The purpose of this study is to describe the improvement of fourth grade student learning outcomes at SD 4 Karangbener through the application of the Jigsaw learning model. This research is a classroom action research conducted for 2 cycles, each cycle consists of 2 meetings. Each cycle consists of 4 stages, namely: planning, implementing actions, observing, and reflecting. The subjects of this study were teachers and fourth grade students of SD 4 Karangbener Bae Kudus, totaling 19 students. The method of data collection was done through tests, interviews, observations, and documentation. The instruments used were in the form of observation sheets for teaching teacher skills, observation sheets for students' affective and psychomotor aspects of learning outcomes, multiple choice tests, and interview guide sheets. The data analysis used is quantitative and qualitative data analysis.

The results of this study showed that the first cycle obtained a percentage of $68.42 \%$, an increase of $89.50 \%$ in the second cycle. Affective domain student learning outcomes in the first cycle an average score of 14 (good) increased to 16.64 (very good) in the second cycle. While the psychomotor learning outcomes obtained an average score of 15.5 (good) increased by 18 (very good) in the second cycle. The researcher concludes that the use of the jigsaw learning model can improve learning outcomes in learning theme 6 my ideals in class IV SD 4 Karangbener.

\footnotetext{
Abstrak

Tujuan penelitian ini yaitu mendeskripsikan peningkatan hasil belajar siswa kelas IV SD 4 Karangbener melalui penerapan model pembelajaran Jigsaw.

Penelitian ini merupakan penelitian tindakan kelas yang dilakukan selama 2 siklus, setiap siklus terdiri dari 2 pertemuan. Tiap siklus terdiri dari 4 tahap, yaitu: perencanaan, pelaksanaan tindakan, pengamatan, dan refleksi. Subjek penelitian ini adalah guru dan siswa kelas IV SD 4 Karangbener Bae Kudus yang berjumlah 19 siswa. Metode pengumpulan data dilakukan melalui tes, wawancara, observasi, dan dokumentasi. Instrumen yang digunakan berupa lembar pengamatan keterampilan guru mengajar, lembar pengamatan hasil belajar aspek afektif dan psikomotorik siswa, tes pilihan ganda, dan lembar pedoman wawancara. Analisis data yang digunakan yaitu analisis data kuantitatif dan kualitatif.

Hasil penelitian ini menunjukkan siklus I memperoleh persentase $68,42 \%$ meningkat $89,50 \%$ pada siklus II. Hasil belajar siswa ranah afektif pada siklus I skor rata-rata 14 (baik) meningkat menjadi 16,64 (sangat baik) pada siklus II. Sedangkan hasil belajar ranah psikomotorik memperoleh skor rata-rata 15,5 (baik) meningkat 18 (sangat baik) pada siklus II. Simpulan peneliti bahwa penggunaan model pembelajaran jigsaw dapat meningkatkan hasil belajar pada pembelajaran tema 6 cita-citaku kelas IV SD 4 Karangbener.
} 


\section{PENDAHULUAN}

Belajar sebagai aktifitas baik secara fisik maupun mental yang menghasilkan sebuah perubahan baik perubahan secara pengetahuan, sikap, maupun keterampilan. Perubahan tersebut dapat tercapai apabila terdapat keterlibatan aktif dari siswa dalam proses pembelajaran. Pembelajaran berpusat pada siswa (Center Student Learning) diharapkan dapat diterapkan oleh guru dalam pembelajarannya. Melalui pembelajaran yang berpusat pada siswa akan membantu dalam membentuk proses pembelajaran bermakna yang berdampak pada peningkatan kualitas pembelajaran dan hasil belajar siswa.

Hasil belajar sebagai tujuan pembelajaran yang diharapkan dapat tercapai dengan baik oleh siswa. Hasil belajar terdiri dari 3 ranah yaitu ranah kognitif, afektif, dan psikomotorik. Ketiga ranah ini harus dikuasai oleh siswa dengan baik. Ranah kognitif berkenaan dengan hasil belajar intelektual dan paling menonjol dibandingkan lainnya. Ranah afektif berkenaan dengan sikap dan nilai siswa saat pembelajaran. Sedangkan ranah psikomotoris berkenaan dengan hasil belajar keterampilan dan kemampuan bertindak. Ketercapaian tujuan pembelajaran merupakan salah satu indikator dari keberhasilan sebuah proses pembelajaran. Proses pembelajaran yang dapat membantu ketercapaian tujuan pembelajaran adalah proses pembelajaran yang dapat melibatkan siswa aktif di dalamnya (Hertiavi dkk, 2010). Siswa aktif berpendapat, bertanya, dan berdiskusi. Keaktifan siswa inilah yang dapat mendukung pencapaian hasil belajar sebagai salah satu tercapainya tujuan pembelajaran.

Berdasarkan hasil observasi yang dilakukan pada siswa kelas IV SD 4 Karangbener diketahui bahwa proses pembelajaran didominasi oleh metode ceramah, sehingga siswa cenderung pasif. Selain itu, siswa lebih cepat merasa bosan dengan pembelajaran karena siswa tidak terlibat secara aktif dalam pembelajaran. Beberapa siswa lebih memilih untuk berbicara dengan teman sebangkunya atau sesekali berbuat keributan di kelas. Siswa hanya diam ketika diberikan pertanyaan dari guru ataupun ketika diberikan kesempatan untuk bertanya. Berdasarkan hasil nilai ulangan harian diketahui bahwa hanya sebesar 9 siswa dari 19 siswa atau 47,37\% siswa yang memperoleh hasil belajar di atas Kriteria Ketuntasan Minial (KKM).

Hasil wawancara dengan siswa juga diketahui bahwa dalam proses pembelajaran siswa merasa jenuh karena hanya duduk mendengarkan ceramah. Siswa menyebutkan bahwa siswa suka belajar secara kelompok, karena dengan belajar kelompok dapat saling berdiskusi dan memecahkan permasalahan secara bersama. Guru juga mengungkapkan bahwa proses pembelajaran yang dilakukan selama ini hanya dengan menjelaskan materi. Selain itu, guru juga menyampaikan bahwa siswa kurang aktif dalam kegiatan pembelajaran, jarang siswa yang mau bertanya apalagi menjawab pertanyaan dari guru. Keaktifan di kelas hanya didominasi oleh siswa yang memiliki kemampuan tinggi saja, sehingga siswa lainnya tidak terbiasa dan lebih memilih diam saja.

Kualitas pembelajaran juga ditentukan oleh peran guru. Guru harus mampu merencanakan pembelajaran yang dapat mengaktifkan siswa. Penggunaan model pembelajaran dapat membantu meningkatkan aktivitas siswa (Sudarsana, 2018). Salah satu model pembelajaran yang dapat mengaktifkan siswa dalam kegiatan pembelajaran adalah model Jigsaw. Lei dalam Rusman (2014) menyatakan bahwa jigsaw merupakan salah satu tipe model pembelajaran kooperatif yang fleksibel. Pada model pembelajaran jigsaw siswa dibagai menjadi beberapa kelompok (Pratiwi, 2015). Masing-masing kelompok mengirimkan perwakilan sebagai utusan sebagai tim ahli. Tim ahli yang bertugas membahas permasalaahan yang dihadapi, selanjutnya hasil pembahasan itu dibawa ke kelompok asal dan disampaikan pada anggota timnya. Penerapan model Jigsaw dapat meningkatkan aspek afektif, kognitif dan psikomotorik siswa pad muatan bahasa Indoneia dan IPS. Model Jigsaw dapat meningkatkan aktivitas siswa terutama aktivitas dalam berdiskusi dan menjelaskan (Widiastini $\mathrm{dkk}, 2014)$. Kelebihan model jigsaw ini dapat membantu siswa untuk belajar memecahkan permasalahan secara kelompok dan belajar sebuah konsep dari temannya sendiri.

Penelitian ini sejalan dengan penelitian Hanafi, dkk (2016) bahwa hasil belajar siswa kelas semakin meningkat dengan penerapan model Jigsaw. Hasil ketuntasan pada tes awal yaitu ketuntasan belajar klasikal 47,36\% serta daya serap klasikal 64,86\%. Hasil belajar siklus I yaitu ketuntasan belajar klasikal 65,79\% serta daya serap klasikal $67,11 \%$. Sedangkan pada siklus II mengalami peningkatan dengan ketuntasan belajar klasikal $86,84 \%$ dan daya serap klasikal sebesar 73,8\%. Berdasarkan data di atas, maka disimpulkan bahwa penerapan model pembelajaran kooperatif tipe Jigsaw dapat meningkatkan hasil belajar siswa pada pembelajaran IPS di kelas IV SD. Selain itu 
penerapan model Jigsaw dapat memberikan pengalaman belajar bagi siswa dan dapat meningkatkan hasil belajar siswa.

Tujuan penelitian ini yaitu mendeskripsikan peningkatan hasil belajar siswa kelas IV SD 4 Karangbener melalui penerapan model pembelajaran Jigsaw.

\section{METODE PENELITIAN}

Kegiatan Penelitian Tindakan Kelas (PTK) ini dilaksanakan di SD 4 Karangbener, Kecamatan Bae Kabupaten Kudus. Subjek dalam penelitian tindakan kelas ini adalah siswa kelas IV berjumlah 19 orang yang terdiri dari 12 siswa laki-laki dan 7 siswa perempuan. Menurut Sugiyono (2010: 61) variabel bebas adalah variabel yang mempengaruhi atau yang menjadi sebab perubahannya atau timbulnya variabel dependen (terikat). penelitian ini variabel bebasnya adalah Model pembelajaran Jigsaw. Variabel terikat yaitu variabel yang dipengaruhi atau yang menjadi akibat karena adanya variabel bebas. Pada penelitian ini variabel terikatnya adalah hasil belajar pada pembelajaran tema Cita-citaku kelas IV SD 4 Karangbener.

Desain penelitian yang digunakan adalah model dari Kemmis dan MC Taggart dalam Sanjaya (2013) yang terdiri dari 4 siklus atau fase kegiatan, meliputi: perencanaan (planning), pelaksanaan tindakan (action), observasi (observation), dan refleksi (reflection). Teknik pengumpulan data dalam penelitian ini meliputi tes, wawancara, observasi, dan dokumentasi. Analisis data yang digunakan yaitu data kuantitatif dan data kualitatif. Data kuantitatif diperoleh dari hasil tes tertulis yang diberikan pada siswa di setiap akhir siklus. Sedangkan data kualitatif dari hasil pengamatan keterampilan guru mengajar, penilaian hasil belajar siswa pada ranah afektif dan psikomotorik.

Indikator keberhasilan penelitian ini yaitu minimal 75\% siswa kelas IV SD 4 Karangbener mengalami ketuntasan hasil belajar individual sebesar $\geq 75$ dalam pembelajaran tema 6 muatan Bahasa Indonesia dan PPKn.

\section{HASIL DAN PEMBAHASAN}

Pada penelitian tindakan kelas ini dilakukan di kelas IV SD 4 Karangbener pada pembelajaran subtema cita-cita dengan menggunakan model pembelajaran jigsaw. Dari hasil evaluasi yang dilaksanakan tiap akhir siklus dengan menggunakan metode tes, ranah kognitif menunjukkan peningkatan diantaranya pada pra siklus memperoleh ketuntasan $47,37 \%$ dengan kualifikasi sedang. Pada siklus I persentase ketuntasan meningkat menjadi $68,42 \%$ namun masih belum mencapai indikator keberhasilan yang dicapai yaitu $75 \%$. Namun pada siklus II persentase ketuntasan mengalamai yaitu mencapai $89,50 \%$ bahkan sampai melebihi target indikator keberhasilan yaitu $>75 \%$. Hal ini dikatakan hasil belajar ranah kognitif menigkat pada pembelajaran subtema cita-citaku menggunakan model pembelajaran jigsaw.Rekapitulasi nilai dilakukan pada setiap siswa mulai dari prasiklus, tes evaluasi siklus I sampai tes evaluasi siklus II. Hasil nilai siswa dari prasiklus, siklus I, siklus II menunjukkan peningkatan hasil belajar siswa.

Tabel 1. Ketuntasan Penilaian Kognitif Nilai Pra Siklus, Siklus I dan Siklus II

\begin{tabular}{cccc}
\hline \multirow{2}{*}{ Kriteria } & \multicolumn{3}{c}{ Persentasi Ketuntasan (\%) } \\
\cline { 2 - 4 } & Pra Siklus & Siklus I & Siklus II \\
\hline Tuntas & 47,37 & 68,42 & 89,50 \\
$\begin{array}{c}\text { Tidak } \\
\text { tuntas }\end{array}$ & 52,63 & 31,58 & 10,50 \\
\hline Jumlah & 100 & 100 & 100 \\
\hline
\end{tabular}

Data pada Tabel 1 menunjukkan bahwa terjadi peningkatan nilai tes siswa pada pembelajaran subtema cita-cita menggunakan model jigsaw dari prasiklus, siklus I ke siklus II. Pada pra siklus siswa yang tidak tuntas sebanyak 10 siswa dengan persentase $48 \%$ sedangkan siswa yang tuntas ada 9 siswa dengan persentase $47,37 \%$. Siklus I, siswa yang tuntas meningkat sebanyak 13 siswa dengan persentase $68,42 \%$ dan siswa yang belum tuntas sebanyak 6 siswa dengan persentase 31,58\%. Siklus II siswa yang tuntas meningkat lagi sebanyak 17 siswa dengan persentase $89,50 \%$ dan siswa yang belum tuntas ada 2 siswa dengan persentase $10,50 \%$. Ketuntasan klasikal hasil belajar kognitif siswa siklus I sebesar $68,42 \%$ meningkat menjadi $89,50 \%$ pada siklus II, ketuntasan klasikal ini sudah melebihi ketuntasan klasikal minimal yang ditetapkan yakni $75 \%$ sehingga dinyatakan berhasil.Selain ranah kognitif siswa hasil observasi terhadap hasil afektif siswa juga mengalami peningkatan pada siklus I ke siklus II, peningkatan hasil belajar afektif siklus I dan siklus II dapat dilihat pada tabel berikut. Persentase hasil belajar ranah sikap/afektif siswa siklus I sebesar 70\% dengan kategori baik meningkat pada siklus II menjadi $83 \%$ dengan kategori sangat baik. Kriteria ini telah memenuhi kriteria minimal yang ditetapkan yakni tinggi dengan persentase $75 \%$, sehingga dinyatakan berhasil.

Selain ranah afektif siswa hasil observasi terhadap hasil psikomotorik siswa juga mengalami peningkatan pada siklus I ke siklus II. Persentase hasil belajar ranah psikomotorik 
siswa siklus I sebesar $65,31 \%$ dengan kategori baik meningkat pada siklus II menjadi 76,98\% dengan kategori sangat baik. Kriteria minimal yang ditetapkan yakni tinggi dengan persentase $75 \%$, sudah terpenuhi sehingga dinyatakan berhasil.

Hasil penelitian dan analisis data yang ada menunjukkan bahwa penerapan model Jigsaw meningkatkan hasil belajar siswa kelas IV SD 4 Karangbener pada subtema Cita-citaku. Peningkatan tersebut ditunjukkan setelah dilakukan tindakan pada siklus I dan siklus II yang masing-masing terdiri dari 2 pertemuan.

Perbandingan hasil rata-rata persentase hasil belajar ranah kognitif siswa pada siklus I dan siklus II dapat dilihat dalam Tabel 2 berikut ini.

Tabel 2. Rata-rata presentase hasil belajar ranah

\begin{tabular}{lcc} 
& kognitif & \\
\hline \multicolumn{1}{c}{ Siklus } & Siklus I & Siklus II \\
\hline $\begin{array}{l}\text { Rata-rata } \\
\text { persentase } \\
\text { Kriteria }\end{array}$ & $68,42 \%$ & $89,50 \%$ \\
\hline
\end{tabular}

Berdasarkan analisis data hasil belajar ranah kognitif siswa pada siklus I diperoleh rata-rata kelas dengan nilai 73,09 dengan presentase $68,42 \%$ (tinggi) dimana terdapat 13 siswa mencapai nilai KKM dan 6 siswa memperoleh dibawah KKM. Pada pembelajaran siklus I ini masih banyak siswa yang main sendiri, sibuk ngobrol dengan teman sebangku selain itu pada saat mempresentasikan hasil diskusi banyak siswa yang membacanya dengan suara pelan sehingga tidak terdengar sampai kebelakang. Hal ini menyebabkan pemahaman siswa mengenai materi yang diajarkan masih kurang dan hasil belajar masih belum memenuhi kriteria yang diaharapkan. Sehingga perlu dilakukannya tindakan perbaikan pada siklus selanjutnya agar hasil belajar siswa dapat meningkat.

Pada siklus II menunjukkan hasil belajar meningkat dengan diperolehnya rata-rata kelas dengan nilai 80 dengan presentase $89,50 \%$ (sangat tinggi) dimana terdapat 17 siswa mencapai nilai KKM dan 2 siswa memperoleh dibawah KKM. Hasil belajar dapat meningkat dikarenakan guru dalam menggunakan media pembelajaran, sarana dan prasarana yang memadai sehingga siswa senang saat mengikuti proses pembelajaran dan merasa nyaman ketika berada didalam kelas. Dengan menggunakan model jigsaw, mereka dapat lebih mudah memahami materi dengan cara yang menyenangkan. Siswa menjadi lebih aktif dan antusias dalam belajar.
Siswa yang belum tuntas ada 2 siswa antara lain AZ dan QIZ. Siswa yang bernama AZ tidak tuntas diakibatkan dalam pembelajaran cenderung gaduh di kelas dan sering mengganggu temannya. Sebagaimana dijelaskan oleh Sutikno (2013) bahwa salah satu faktor yang mempengaruhi hasil belajar adalah faktor internal meliputi kondisi psikologis yakni sikap dalam belajar. Sedangkan yang bernama QIZ karena siswa tersebut kurang konsentrasi, pemalu, cenderung diam dan pasif dalam pembelajaran. Hal ini sama sejalan dengan pendapat Sutikno (2013) bahwa faktor yang mempengaruhi hasil belajar meliputi meliputi kondisi psikologis yakni sikap dalam belajar. Sedangkan yang bernama QIZ karena siswa tersebut kurang konsentrasi, pemalu, cenderung diam dan pasif dalam pembelajaran. Hal ini sama sejalan dengan pendapat Sutikno (2013) bahwa faktor yang mempengaruhi hasil belajar meliputi faktor internal salah satunya adalah kondisi psikologis seperti konsentrasi belajar, rasa percaya diri siswa, dan intelegensi.

Perbandingan hasil rata-rata persentase hasil belajar ranah afektif siswa pada siklus I dan siklus II dapat dilihat dalam Tabel 3 berikut ini.

Tabel 3. Rata-rata presentase hasil belajar ranah

\begin{tabular}{lcc} 
& afektif & \\
\hline \multicolumn{1}{c}{ Siklus } & Siklus I & Siklus II \\
\hline $\begin{array}{l}\text { Rata-rata } \\
\text { persentase } \\
\text { Kriteria }\end{array}$ & $66 \%$ & $81 \%$ \\
\hline
\end{tabular}

Peningkatan pembelajaran pada ranah afektif dalam menerapkan model Jigsaw pada pembelajaran subtema cita-citaku muatan Bahasa Indonesia dan PPKn dapat dilihat dari hasil pada siklus I pertemuan 1 diperoleh persentase $61 \%$ dengan kualifikasi cukup, sedangkan pada siklus I pertemuan 2 diperoleh persentase 71 dengan kualifikasi baik, jadi ratarata klasikal pada siklus I diperoleh persentase klasikal 66\% (baik). Sedangkan pada siklus II pertemuan 1 mendapatkan persentase $77 \%$ dengan kualifikasi baik, pada siklus II pertemuan 2 memperoleh persentase $85 \%$ dengan kualifikasi sangat baik. Jadi rata-rata klasikal pada siklus II diperoleh persentase $81 \%$ (sangat baik). Hasil belajar siswa pada ranah afektif mengalami peningkatan disetiap siklusnya. Peningkatan ini dikarenakan penerapan model jigsaw. Dengan model jigsaw siswa lebih aktif dalam pembelajaran (Susanti, 2019)

Perbandingan hasil rata-rata persentase hasil belajar ranah psikomotorik siswa pada 
siklus I dan siklus II dapat dilihat dalam Tabel 4 berikut ini.

Tabel 4. Rata-rata presentase hasil belajar ranah

\begin{tabular}{lcc}
\multicolumn{3}{c}{ psikomotorik } \\
\hline \multicolumn{1}{c}{ Siklus } & Siklus I & Siklus II \\
\hline $\begin{array}{l}\text { Rata-rata } \\
\text { persentase }\end{array}$ & $65 \%$ & $83,75 \%$ \\
Kriteria & baik & Sangat baik \\
\hline
\end{tabular}

Peningkatan hasil belajar pada ranah psikomotorik dalam menerapkan model Jigsaw pada pembelajaran subtema cita-citaku muatan Bahasa Indonesia dan PPKn dapat dilihat dari hasil analisis terhadap lembar pengamatan ranah psikomotorik. Pada siklus I pertemuan I diperoleh persentase $62,50 \%$ dengan kualifikasi cukup, pada pertemuan II diperoleh persentase $67,50 \%$ dengan kualifikasi baik. Jadi skor ratarata klasikal pada siklus I memperoleh persentase $65 \%$ kualifikasi baik karena sudah melebihi indikator keberhasilan. Sedangkan pada siklus II pertemuan 1 diperoleh persentase $78,75 \%$ kualifikasi baik, siklus II pertemuan 2 memperoleh persentase $88,75 \%$ kualifikasi sangat baik, untuk rata-rata dari keseluruhan dari pertemuan I dan pertemuan II pada siklus II mendapat skor sangat melebihi indikator keberhasilan yang ditentukan dengan perolehan persentase $83,75 \%$ (sangat baik).

\section{SIMPULAN}

Hasil belajar siswa ranah kognitif mengalami peningkatan dari prasiklus, siklus I dan siklus II meningkat dibuktikan dengan perolehan rata-rata persentase $89,50 \%$. Peningkatan hasil belajar ranah afektif dari siklus I dan siklus II dengan perolehan persentase $70 \%$ menjadi persentase $83 \%$. Hasil belajar siswa pada ranah psikomotorik mengalami peningkatan dari siklus I dan siklus II meningkat dibuktikan dengan perolehan persentase $65,31 \%$ menjadi persentase $76,98 \%$ (sangat baik).

\section{DAFTAR PUSTAKA}

Hanafi, P., Jamaludin, J., \& Hasdin, H. (2016). Penerapan Model Pembelajaran Jigsaw Untuk Meningkatkan Hasil Belajar Ilmu Pengetahuan Sosial (IPS) Siswa Kelas V SD Inpres Salabenda Kecamatan Bunta Semester I Tahun Pelajaran 2013/2014. Jurnal Kreatif Tadulako Online, 4(11), 200-209.

Hertiavi, M. D., Langlang, H., \& Khanafiyah, S. (2010). Penerapan model pembelajaran kooperatif tipe jigsaw untuk peningkatan kemampuan pemecahan masalah siswa SMP. Jurnal pendidikan fisika Indonesia, 6(1).

Pratiwi, I. A. (2015). Pengembangan model kolaborasi Jigsaw Role Playing sebagai upaya peningkatan kemampuan bekerjasama siswa kelas V SD pada pelajaran IPS. Jurnal Konseling Gusjigang, 1(2), 107630.

Rusman. 2016. Model-model pembelajaran mengembangkan Profesionalisme guru.PT. Raja Grafindo Persada : Jakarta.

Sanjana, Wina. 2009. Penelitian Tindakan Kelas. Jakarta: Kencana Prenadamedia.

Sudarsana, I. K. (2018). Pengaruh model pembelajaran kooperatif terhadap peningkatan mutu hasil belajar siswa. Jurnal Penjaminan Mutu, 4(1), 20-31.

Sugiyono. 2010. Metode Penelitian Pendidikan Pendekatan Kuantitatif Kualitatif dan $R \& D$. Bandung: Alfabeta.

Susanti, E. (2019). Kemampuan Berpikir Kritis Siswa Sdn Margorejo VI Surabaya melalui Model Jigsaw. Bioedusiana: Jurnal Pendidikan Biologi, 4(1), 55-64.

Sutikno, S. (2013). Belajar dan pembelajaran. Lombok: Holistica.

Widiastini, M., Kusmariyatni, N., \& Arini, N. W (2014). Keefektifan model pembelajaran kooperatif tipe jigsaw untuk meningkatkan hasil belajar IPS Siswa kelas V. MIMBAR PGSD Undiksha, 2(1). 